\title{
Principal Aliphatic Secondary Amines of Burley Tobacco*
}

\author{
by Lowell Bush \\ Department of Agronomy, University of Kentucky, Lexington, Kentucky, USA
}

\section{INTRODUCTION}

Investigations on tobacco bases have been mostly confined to nicotine and other alkaloids but recent reports have been concerned with separation and identification of the volatile amines present in tobacco $(4,11)$. Earlier investigations were hindered by lack of adequate procedures for isolation and detection of amines in plant tissue $(9,10)$. Richardson (7) reported the use of 1 -fluoro-2,4-dinitrobenzene as a quantitative reagent for the determination of simple plant amines. Separation and identification of 17 volatile amines in tobacco were accomplished by use of 4 -nitroazobenzene- 4 '-carboxamide derivatives (6). Among those identified in burley tobacco were dimethylamine, methylethylamine and methylpropylamine. Yasumatsu and Akaike (11) identified 12 amines in tobacco including dimethylamine and diethylamine. In an early survey of volatile amines in flowering plants von Kamenski (10) reported the presence of methylamine and iso-. pentylamine in tobacco. He observed that the amine content of Mercurialis perennis was influenced by the location where plant was grown and by the plant tissue assayed. He also reported that the quantities of amines in $M$. annua were less after periods of wilting than in the fresh tissue. Yasumatsu and Akaike (1I) demonstrated differences in the amounts of several volatile anines between shoot and root, air-cured and fluecured leaves, and nitrogen fertilization in Yellow Bright tobacco. Recently, Bush et al. (I) have shown with cured burley tobacco, produced under commercial production conditions, that increased secondary amine content in tobacco tissue was positively correlated with nitrogen content and that secondary amine content was lowest in leaf tissue from the lower stalk positions.

The objectives of these investigations were to determine the influence of different tobacco tissue and tissue processing and of nitrogen fertilization on the volatile aliphatic secondary amines in tobacco cultured under a semi-controlled environment.

\footnotetext{
- This investigation (No. 70-3-95) is in connection with a project of the Kentudy Experiment Station and is published with approval of the Director. The work was supported by Crops Research Division, Agricultural Research Service, United States Department of Agriculture Contract (No. 12-14-100-9523-34).

Received for publication: 4th July, 1970.
}

\section{EXPERIMENTAL}

\section{Plant Culture}

All tobacco plants were cultured in the greenhouse at $30^{\circ} \mathrm{C}$ with a $15 \mathrm{hr}$. light period and $9 \mathrm{hr}$. dark period. Plants were watered daily with Hoagland nutrient solution (3). Plants used in the experiments designed to study influence of nitrogen on amines were watered with the standard nutrient solution, or with $2 X$ or $4 X$ the standard amounts of $\mathrm{KNO}_{3}$ and $\mathrm{Ca}\left(\mathrm{NO}_{3}\right)_{2}$. Plants of $N$. tabacum were harvested at the 15-20 leaf stage (10-11 weeks of age). Other Nicotiana spp. were harvested at the time of flower bud development. Ovendried material was prepared by drying tissue for $24 \mathrm{hrs}$. in forced draft oven at $70^{\circ} \mathrm{C}$. The air-dried leaf tissue was prepared by priming the leaves and drying in the laboratory at room temperature. All dried plant material was ground to pass a 40 mesh screen prior to analysis. Experiments were duplicated $2-4$ times with 3 replications per experiment where appropriate.

Fresh tissue was macerated for $3 \mathrm{~min}$. in a blender with $1: 2(w / v)$ of $3 \% \mathrm{NaOH}$ and immediately steam distilled. Five-gram samples of dried ground leaf lamina in $50 \mathrm{ml}$ of $3 \% \mathrm{NaOH}$ were steam distilled. The distillate was collected in $100 \mathrm{ml} \mathrm{CH} \mathrm{Cl}_{2}, 50 \mathrm{ml} \mathrm{H}_{2} \mathrm{O}$ and $5 \mathrm{ml}$ conc. $\mathrm{HCl}$. Four hundred $\mathrm{ml}$ of distillate were collected, stirred for $30 \mathrm{~min}$. and the aqueous layer washed once with fresh $\mathrm{CH}_{2} \mathrm{Cl}_{2}$. The 2,4-dinitrophenyl derivatives of the volatile amines were made from the aqueous layer with I-fluoro-2,4-dinitrobenzene (DNFB) and extracted with cyclohexane. An aliquot of the cyclohexane was concentrated and the individual amine derivatives separated by TLC with Silica Gel G adsorbent and hexane: ether, 70:30 (v/v) solvent system (2). Concentration of individual amines was determined by elution with acetone and spectrophotometric measurement at $355 \mathrm{~nm}$. This procedure will detect free amines and any amines formed during base hydrolysis. More specific details of the procedures are published elsewhere $(1,2)$.

Individual aliphatic secondary amines - dimethylamine, methylethylamine, and diethylamine mixed with methylpropylamine - were separated and quantified as derivatives of DNFB. On the thin-layer chromatograms $\mathrm{N}$-methyl-n-propylamine and diethylamine had the 
same migration and these amines were estimated together using a diethylamine standard.

Acidic and basic extracts of the tobacco tissue were prepared by homogenizing tissue in $1 \mathrm{~N} \mathrm{HCl}$ or $1 \mathrm{~N}$ $\mathrm{KOH} 1: 30(w / v)$. The homogenate was filtered through Whatman $\neq_{I}$ and the filtrate washed three times with chloroform. The DNFB derivatives were made directly from the aqueous fraction after adjusting the $\mathrm{pH}$ to approximately 4 before adding the reagents or the aqueous fraction was steam distilled and the derivatives formed. The residue from the filtration and the combined chloroform washings (neutral fraction) were also steam distilled and analyzed. Portions of the aqueous filtrate from the acidic or basic extracts were titrated to $\mathrm{pH} 3.0$ and extracted with $\mathrm{n}$-butanol. The amine derivatives were made on the aqueous fraction of $\mathrm{pH} 3.0$ before and after steam distillation. The butanol fraction was also analyzed for amines.

\section{RESULTS}

Method of leaf processing had a pronounced influence on the levels of dimethylamine, but very little influence on the diethylamine fraction (Table 1 ). Air-drying and oven-drying of the tissue reduced the quantity of dimethylamine by $25 \%$ but the quantity of diethylamine was not changed. Freeze-dried tissue contained quantities of all the amines equal to the fresh tissue. Burley tobacco leaf samples were also assayed fresh and after air-curing and in general the curing process did not influence the quantities of the amines studied.

Contents of the principal volatile secondary aliphatic amines differed with plant parts (Table 2). The stem contained the highest quantity of the three amine fractions measured and the leaf midrib contained the lowest amounts. The methylethylamine content was a greater portion of the total amines measured in the seed, stem and roots than in the leaf lamina and leaf midrib. Methylethylamine content in the seed and stem was equal to the dimethylamine content. Many unidentified dinitrophenylamine derivatives were observed on the TL chromatograms from the root samples that were not observed in the other samples. Removing the apical meristem from the growing tobacco plants (topping) prior to harvesting had no influence on the amine content. Also, the age of plants had no consistent influence on the amine content.

Table 1. Influence of drying process on the quantities of dimethylamine, methylethylamine, and diethylamine in burley tobacco leaf.

\begin{tabular}{|c|c|c|c|}
\hline \multirow{2}{*}{$\begin{array}{l}\text { Drying } \\
\text { process }\end{array}$} & \multicolumn{3}{|c|}{ Micrograms per gram dry weight } \\
\hline & $\begin{array}{l}\text { Dimethyl- } \\
\text { amine }\end{array}$ & $\begin{array}{c}\text { Methylethyl- } \\
\text { amine }\end{array}$ & $\begin{array}{l}\text { Diethyl- } \\
\text { amine* }\end{array}$ \\
\hline Fresh & 43 & trace & 9 \\
\hline Air-dried & 31 & trace & 8 \\
\hline Oven-dried & 33 & trace & 10 \\
\hline Freeze-dried & 42 & trace & 9 \\
\hline
\end{tabular}

* diethylamine with methylpropylamine.
Not only did the various plant parts differ in amine content but the lamina of different species of Nicotiana or varieties of $N$. tabacum also differed in amine content. $N$. glutinosa had similar ratios among the three amines as the $N$. tabacum but the quantities were much lower (Table 3). N. langsdorffia and N. longiflora contained high total amounts of the amines and most was present as dimethylamine. N. rustica and $N$. suaveolens also contained predominantly dimethylamine but the total amount was intermediate. $N$. glauca contained the lowest amounts of the amines of any species analyzed and most was dimethylamine. Very little difference was observed in the aliphatic amines between the burley lines isogenic for nicotine.

The influence of nitrogen fertilization and nitrogen content of tissue on amine content under field conditions has been reported (I). Culturing tobacco in the greenhouse and watering with nutrient solution containing the standard $(85 \mathrm{mg} \mathrm{N} / 1)$, or $2 \times$, or $4 \times$ the standard amounts of $\mathrm{NO}_{3}-\mathrm{N}$ produced similar results. Data presented in Fig. 1 is the summation of dimethylamine, methylethylamine and diethylamine fractions in leaf lamina. Experiments were run in succession and differences among experiments can only be explained by difference in growth patterns. Within each experiment a linear relationship existed between nitrogen content and amines. The regression line for these data is $X=27.2+15.16 \mathrm{X}$.

Table 2. Dimethylamine, methylethylamine, and diethylamine content in different tissue of oven-dried burley tobacco, Nicotiana tabacum var. Burley 21.

\begin{tabular}{|c|c|c|c|}
\hline \multirow[b]{2}{*}{ Tissue } & \multicolumn{3}{|c|}{ Micrograms per gram dry weight } \\
\hline & $\begin{array}{l}\text { Dimethyl- } \\
\text { amine }\end{array}$ & $\begin{array}{c}\text { Methylethyl- } \\
\text { amine }\end{array}$ & $\begin{array}{l}\text { Diethyl- } \\
\text { amine* }\end{array}$ \\
\hline Seed & 6 & 8 & trace \\
\hline Leaf lamina & 14 & 3 & 7 \\
\hline Leaf midrib & 2 & 1 & 4 \\
\hline Stem & 14 & 13 & 9 \\
\hline Roots & 13 & 7 & 5 \\
\hline
\end{tabular}

Table 3. Dimethylamine, methylethylamine, and diethylamine content in several $\mathbf{N i c o t i a n a}$ species.

\begin{tabular}{l|c|c|c}
\hline \multicolumn{1}{c|}{ Species } & \multicolumn{3}{|c}{ Micrograms per gram dry weight } \\
& $\begin{array}{c}\text { Dimethyl- } \\
\text { amine }\end{array}$ & $\begin{array}{c}\text { Methylethyl- } \\
\text { amine }\end{array}$ & $\begin{array}{c}\text { Diethyl- } \\
\text { amine* }\end{array}$ \\
\hline N. glauca & 9 & trace & trace \\
N. rustica & 22 & trace & trace \\
$\begin{array}{l}\text { N. langsdorffia } \\
\text { N. longiflora }\end{array}$ & 75 & N.D.** & 6 \\
$\begin{array}{l}\text { N. suaveolens } \\
\text { N. glutinosa }\end{array}$ & 52 & N.D. & 2 \\
N. tabacum \\
$\begin{array}{l}\text { var. Burley 21 } \\
\text { var. Burley 21 }\end{array}$ & 33 & trace & trace \\
low-nicotine & 17 & trace & 10 \\
$\begin{array}{l}\text { Ky Iso 7 } \\
\text { (Turkish) }\end{array}$ & 44 & 3 & 35 \\
\hline
\end{tabular}

* diethylamine with methylpropylamine.

** not detected. 
Figure 1. Infuence of total nitrogen on aliphatic secondary amines in tobacco leaf tissue.

Aliphatic secondary amine content was calculated from dimethylamine, methylethylamine, diethylamine and methylpropylamine content of the tissue.

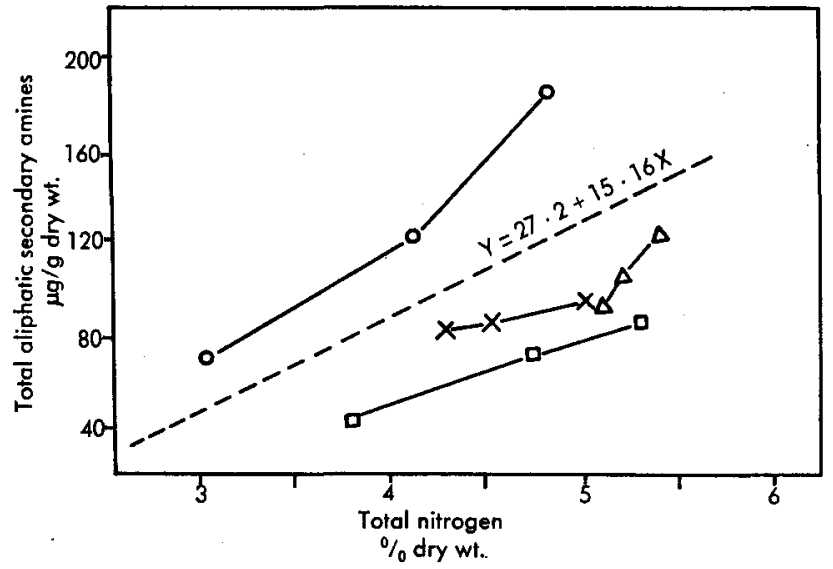

The amines measured in these experiments are readily soluble in aqueous media, thus should be extractable and detectable as the dinitrophenylamine derivatives without steam distillation. Amine analysis following extraction of tissue with $1 \mathrm{~N} \mathrm{KOH}$ or $1 \mathrm{~N} \mathrm{HCl}$ indicated very small amounts of these amines were present in the aqueous media (Table 4 ). The acid fraction represents substances extracted with $\mathrm{KOH}$ and the base fraction represents material extracted with $\mathrm{HCl}$. The amines were apparently in both aqueous extracts because if these extracts were steam distilled the amines were found in appreciable amounts in the distillate. These results suggest that the amines in the aqueous extracts were not present as the free bases.

The presence of the amines in the acid, base or neutral fraction was further examined in fresh tobacco leaf tissue. In this experiment all amine determinations were made after steam distillation and for each treatment a new portion of the sample was used. The acid fraction, extracted with $1 \mathrm{~N} \mathrm{KOH}$, contained essentially all of the diethylamine fraction and $38 \%$ of the dimethylamine (Table 5) compared to the control. The base fraction also contained all of the diethylamine fraction but contained $67 \%$ of the dimethylamine fraction. The nefutral fraction and the residue (tobacco tissue which had been extracted with both $\mathrm{HCl}$ and $\mathrm{KOH}$ prior to steam distillation) contained small amounts of the amines. Of the total amines found in the fresh tobacco tissue $58 \%$ were removable from the tissue with $\mathrm{KOH}$,

Table 4. Effect of steam distillation on apparent volatile aliphatic secondary amine content of acid-base extracts of cured tobacco leaf tissue.

\begin{tabular}{l|c|c|c}
\hline Extract & \multicolumn{3}{|c}{ Micrograms per gram dry weight } \\
& $\begin{array}{c}\text { Dimethyl- } \\
\text { amine }\end{array}$ & $\begin{array}{c}\text { Methylethyl- } \\
\text { amine }\end{array}$ & $\begin{array}{c}\text { Diethyl- } \\
\text { amine* }\end{array}$ \\
\hline $\begin{array}{c}\text { Acid fraction } \\
\begin{array}{c}\text { Acid fraction - } \\
\text { steamed }\end{array}\end{array}$ & 3 & 1 & 1 \\
$\begin{array}{l}\text { Base fraction } \\
\text { Base fraction - } \\
\text { steamed }\end{array}$ & 5 & 15 & 10 \\
\hline
\end{tabular}

* diethylamine with methylpropylamine.
Table 5. Volatile secondary amine content in acidic, basic and neutral extracts from fresh tobacco leaf tissue.

\begin{tabular}{l|c|c|c}
\hline \multicolumn{1}{c|}{ Extract } & \multicolumn{3}{|c}{ Micrograms per gram dry weight } \\
& $\begin{array}{c}\text { Dimethyl- } \\
\text { amine }\end{array}$ & $\begin{array}{c}\text { Methylethyl- } \\
\text { amine }\end{array}$ & $\begin{array}{c}\text { Diethyl- } \\
\text { amine* }\end{array}$ \\
\hline Tobacco & 66 & 2 & 40 \\
Acid fraction & 25 & trace & 38 \\
Base fraction & 40 & trace & 40 \\
Neutral fraction & trace & trace & trace \\
Residue & 5 & trace & 7 \\
\hline
\end{tabular}

* diethylamine with methylpropylamine.

$74 \%$ were removable from the tissue with $\mathrm{HCl}$, and $11 \%$ were not extracted with either solvent.

\section{DISCUSSION}

Results of these experiments indicate that the type of tissue, tissue processing, and nitrogen content of the tissue have significant influence on the quantities of steam volatile aliphatic secondary amines in tobacco. Freeze-drying leaf tissue did not reduce amine content compared to amounts extracted from fresh tissue. Airdrying or oven-drying caused a $25 \%$ reduction in dimethylamine content but did not alter concentrations of the other amine fractions measured. However, normal air-curing of burley tobacco did not appreciably decrease the amine content and presumably this is because the leaf tissue was cured intact with the stalk whereas in our air-drying process primed leaves were used.

Accumulation of amines was significantly altered by the type of tissue and both the high and low extremes of amine concentrations were found in conducting tissue, stem and the leaf midrib. Because of the carcinogenicity of nitrosamines that may be formed in tobacco smoke from secondary amines and nitrous gases, the observation of low amine concentration in the midrib could have important implications in that more midrib tissue is being used in cigarette manufacturing and thereby lowering the amine content of the tobacco in the cigarette.

Considerable variation existed in the amine content among Nicotiana spp. cultured under the same environmental conditions. Based on the observations reported the amine pattern fits the phylogenetic relationships (8) at the subgenus level of Nicotiana. $N$. langsdorffia, $N$. longiflora and $N$. suaveolens are all in the subgenus Petunioides and all have high dimethylamine content compared to the other amine fractions. $N$. glauca and $N$. rustica are in the subgenus Rustica and are low in methylethylamine and diethylamine fractions as the Petunioides group but are lower than Petunioides in dimethylamine. $N$. glutinosa and $N$. tabacum are in the subgenus Tabacum and the diethylamine fraction is $30-40 \%$ of the total amines and dimethylamine accounts for most of the remainder.

Amine content of leaf tissue was positively related to nitrogen content and these studies confirm previous work with burley tobacco cultured in the field ( 1 ). Within each experiment a linear relationship existed 
among nitrogen treatment and amine content, however, reproducibility among experiments was not good. These experiments were replicated in time and the environment in the greenhouse was not the same in all cases. Also, because $\mathrm{Ca}^{+++}$and $\mathrm{K}^{+}$concentrations were not the same in all nutrient solutions the effect of these cations cannot be ignored. Krasaesindhu (5) has suggested an interaction between $\mathrm{Ca}^{++}$and nitrate nitrogen uptake but in the present study the ratio of $\mathrm{Ca}^{+*}$ and $\mathrm{K}^{+}$to $\mathrm{NO}_{3}-$ was always equal and the $\mathrm{Ca}^{++}$or $\mathrm{K}^{+}$ content of the tissue was not measured.

The data indicate that the steam volatile amines measured in these investigations were not present as free bases or simple salts because they were only detected in appreciable quantities after steam distillation or base hydrolysis. The compounds giving rise to the amines were present to a greater extent in the base fraction than the acid fraction of fresh tissue and almost totally absent from the neutral fraction. Using an acidic or basic media $89 \%$ of the amines could be extracted from the tissue. Separation of amines and amides in the acid or base fraction was done by extraction with butanol at $\mathrm{pH}$ 3. The amines should be present in the aqueous layer and the amides in the butanol layer. Of the amines found in the acid fraction $86 \%$ remained in the aqueous layer and $14 \%$ was in the butanol (present as amides). In the base fraction $94 \%$ of the amines detected were present as amines and only $6 \%$ were present in the butanol. These results suggest that steam volatile amines are derived from chemically bound amines in the tissue and the amounts detected may vary with type of binding. This conclusion indicates further work is required to define the chemical nature of these compounds and study amine transfer to smoke and to define the influence these amines have on smoke quality.

\section{SUMMARY}

Quantity and distribution of the principal aliphatic secondary amines - dimethylamine, methylethylamine, diethylamine, and methylpropylamine - varied within plant tissue and among Nicotiana spp. In burley tobacco the stem tissue had the highest content of these amines and the leaf midrib the lowest. Leaf lamina, roots and seed were intermediate in amine content. Among Nicotiana spp. there was considerable difference in total amine content as well as among the ratios of the amine fractions measured. Amine content of tissue was positively correlated with nitrogen content of tissue and was altered by the drying process of tissue prior to analysis. The amines were not present as free amines or salts but were detected only following steam distillation from a basic medium.

\section{ZUSAMMENFASSUNG}

Quantität und Verteilung der hauptsächlichen aliphatischen sekundären Amine - Dimethylamin, Methyläthylamin, Diäthylamin und Methylpropylamin - waren sowohl innerhalb der pflanzlichen Gewebe als auch zwischen verschiedenen Spezies von Nicotiana unterschiedlich. Beim Burley-Tabak hatte das Stengelgewebe den höchsten und die Mittelrippe der Blätter den geringsten Gehalt an diesen Aminen. Die Blatt-Laminae, Wurzeln und Samen wiesen einen mittleren Amingehalt auf. Beim Vergleich verschiedener Nicotiana Spezies ergaben sich beträchtliche Unterschiede sowohl hinsichtlich des Gesamt-Amingehaltes als auch hinsichtlich der Verhältnisse der untersuchten Aminfraktionen. Es zeigte sich eine positive Korrelation zwischen dem Stickstoffgehalt und dem Amingehalt des Gewebes, der sich durch den Trocknungsproze $B$ des Gewebes vor der Analyse veränderte. Die Amine traten nicht als freie Amine oder Salze auf, sondern wurden erst nach Dampfdestillation aus einem basischen Nährboden festgestellt.

\section{RESUME}

La quantité et la répartition des amines aliphatiques secondaires les plus importantes - diméthylamine, méthyléthylamine, diéthylamine, méthylpropylamine - varient à l'intérieur des tissus et suivant les espèces de Nicotiana. Dans le tabac burley, on a trouvé la concentration la plus élevée de ces amines dans la tige, la moins élevée dans la nervure centrale des feuilles. La concentration était intermédiaire dans les feuilles elles-mêmes, dans les racines et les graines. Suivant les espèces de Nicotiana, on a observé des différences importantes des concentrations en amines totales, et dans les proportions des différentes fractions déterminées. La concentration en amine des tissus est en corrélation positive avec leur contenu en azote, et peut varier suivant le procédé de séchage avant l'analyse. Les amines ne sont pas présentes à l'état libre ni comme sels, mais ne purent être détectées qu'après distillation à vapeur d'eau en milieu basique.

\section{REFERENCES}

1. Bush, L. P., Sims, J. L., and Atkinson, W. O.: Can. J. Plant Sci. 50 (1970) 289.

2. Day, E. W., Golab, T., and Koons, J. R.: Anal. Chem. 38 (1966) 1053.

3. Hoagland, D. R., and Arnon, D. I.: Calif. AES Circular 347 (1938).

4. Irvine,W., and Saxby, M.: Phytochem. 8 (1969) 473.

5. Krasaesindhu, P.: Master of Science Thesis, University of Kentucky, 1969.

6. Neurath, G., Krull, A., Pirmann, B., and Wandrey, K.: Beitr. Tabakforsch. 3 (1966) 571.

7. Richardson, M.: Nature 197 (1963) 290.

8. Smith, H. H.: Adv. in Genetics 14 (1969) 1.

9. Steiner, M., and Kamienski, E. S. von: Naturwiss. 40 (1953) 483.

10. Kamienski, E. S. von: Planta 50 (1957) 315.

11. Yasumatsu, N., and Akaike, S.: Nippon Noegi. Kagaku. Kaishi. 39 (1965) 347.

The author's address:

Department of Agronomy, University of Kentucky, Lexington, Kentucky, 40506, USA. 